\title{
BIODEGRADASI PLASTIK OLEH MIKROORGANISME
}

\author{
Annisa Nur Islami \\ Jurusan Teknik Lingkungan, Fakultas Arsitektur Lanskap dan Teknologi Lingkungan, \\ Universitas Trisakti, Jakarta, Indonesia
}

Email korespondensi: annisa08215006@ std.trisakti.ac.id

\begin{abstract}
ABSTRAK
Salah satu polimer kompleks yang memiliki umur degradasi yang sangat lama adalah plastik. Hal tersebut dikarenakan plastik memiliki rantai yang panjang serta berulang sehingga dapat menyebabkan masalah lingkungan yang serius. Mineral dalam tanah baik organik maupun anorganik semakin berkurang dikarenakan plastik yang berada pada tanah tersebut tidak dapat diuraikan oleh mikroorganisme. Akibatnya fauna yang berada di dalam tanah sulit memperoleh oksigen, sumber makanan dan tempat berlindung sehingga akhirnya fauna tersebut mati. Oleh karena hal tersebut perlu dilakukan pengendalian secara aspek biologis dengan mencari kandidat mikroorganisme pendegradasi polimer plastik atau disebut biodegradasi sehingga jumlah sampah plastik dapat diminimalisir. Biodegradasi adalah proses penguraian yang memanfaatkan aktivitas mikroorganisme, sehingga terjadi transformasi struktur dari suatu senyawa yang menyebabkan perubahan integritas molekular. Senyawa hidrokarbon tidak dapat terdegradasi sempurna jika hanya dilakukan oleh satu jenis mikroba tetapi harus dilakukan oleh beberapa jenis mikroba yang memiliki sifat sinergisme dalam bentuk konsorsium. Tujuan dari penulisan karya ilmiah ini adalah untuk mengetahui kemampuan mikroorganisme dalam mendegradasi limbah plastik yang terpapar di lingkungan. Analisis pada proses biodegradasi plastik dapat dilakukan dengan beberapa cara diantaranya Fourier Transform InfraRed (FTIR) yang bertujuan untuk mengetahui perubahan gugus fungsi yang terjadi dan Scanning Electron Microscopy (SEM) yang bertujuan untuk mengetahui perubahan morfologi permukaan plastik.
\end{abstract}

Kata Kunci: Biodegradasi, Mikroorganisme, Plastik

\section{PENDAHULUAN}

Salah satu polimer kompleks yang memiliki umur degradasi yang sangat lama adalah plastik. Hal tersebut dikarenakan plastik memiliki rantai yang panjang serta berulang sehingga dibutuhkan waktu yang cukup lama untuk memecah rantai panjang tersebut menjadi rantai yang lebih pendek (Bhardwaj, 2012). Setiap tahunnya, lebih dari 140 juta ton polimer sintetis diproduksi di seluruh dunia. Karena polimer sangat stabil, siklus degradasinya di alam terbatas. Polusi lingkungan oleh polimer sintetis seperti limbah plastik yang larut dalam air dan air limbah diketahui sebagai masalah utama lingkungan (Joshi, 2010). Beberapa mikroorganisme seperti bakteri, jamur terlibat dapat mendegradasi plastik alami dan sintetis (Archana, 2011).

Plastik yang memiliki sifat transparan, tahan air, ringan dan relatif murah membuatnya semakin banyak digunakan di industri maupun di masyarakat. Hal tersebut menyebabkan peningkatan jumlah produksi plastik sehingga berdampak pula pada jumlah limbah plastik yang timbul(Fadlilah dan Maya, 2014). Berdasarkan hal tersebut, sangat perlu dilakukan pengendalian secara aspek biologis dengan mencari kandidat mikroorganisme pendegradasi polimer plastik sehingga jumlah sampah plastik dapat diminimalisir. Adapun tujuan dari karya ilmiah ini adalah untuk mengetahui kemampuan mikroorganisme dalam mendegradasi limbah plastik yang terpapar di lingkungan.

\section{TINJAUAN PUSTAKA}

\section{Limbah Plastik dan Keberadaannya di Alam}

Plastik yang memiliki banyak kegunaan dan praktis menjadikan penggunaan plastik semakin bertambah dan popular di dunia maupun di Indonesia, sehingga menyebabkan permasalahan lingkungan yang cukup serius. Bahan utama pembuatan plastik yaitu senyawa phthalat ester di(ethylhexyl) phthalat (DEHP) yang memiliki sifat stabil dan sulit didegradasi oleh mikroorganisme, hal tersebut menyebabkan area pembuangan sampah terus-menerus diperlukan. Selama tiga dekade terakhir, bahan plastik banyak digunakan dalam transportasi, makanan, pakaian, konstruksi tempat tinggal, industri medis dan rekreasi, jaring ikan, pengemasan, industri makanan dan bidang pertanian (Anbuselvi, 2014). Dalam kondisi alami, bahan organik yang dapat terdegradasi atau tidak terdegradasi dianggap sebagai masalah lingkungan utama, misalnya 
plastik. Akumulasi limbah plastik ini menciptakan ancaman serius bagi lingkungan dan kehidupan (Takabatake, 2003). Plastik memiliki dampak yang buruk terhadap lingkungan yaitu tercemarnya air tanah dan makhluk bawah tanah, racun yang terdapat di dalam plastik akan masuk ke dalam tanah dan masuk ke dalam tubuh hewan serta tumbuhan sehingga akan menjadi racun berantai mengikuti rantai makanan. Plastik juga dapat mengganggu jalur air, menurunkan kesuburan tanah dan menghalangi sirkulasi dalam tanah (Purwaningrum, 2016).

\section{Biodegradasi dan Faktor Yang Mempengaruhi Biodegradasi}

Biodegradasi adalah proses penguraian zat organik oleh mikroorganisme (terutama bakteri aerob) menjadi zat yang lebih sederhana seperti karbon dioksida, air dan amonia. Senyawa hidrokarbon tidak dapat terdegradasi sempurna jika hanya dilakukan oleh satu jenis mikroba tetapi harus dilakukan oleh beberapa jenis mikroba yang memiliki sifat sinergisme dalam bentuk konsorsium. Biodegradasi dipengaruhi oleh beberapa faktor yaitu jenis substrat, sumber nitrogen, $\mathrm{pH}$, suhu serta kelembaban yang disesuaikan dengan jenis mikroorganisme yang digunakan.

Berikut ini merupakan faktor-faktor yang mempengaruhi biodegradasi antara lain:

1) Substrat

Ukuran dan komponen senyawa yang menyusun substrat merupakan salah satu faktor yang mempengaruhi degradasi. Degradasi akan berlangsung lebih cepat bila ukuran subtrat lebih kecil dan senyawa penyusunnya lebih sederhana. Sebaliknya, jika ukuran substrat lebih besar dan senyawa penyusunnya lebih kompleks dibutuhkan waktu yang lebih lama untuk mendegradasinya.

2) Sumber Nitrogen

Bahan yang banyak digunakan sebagai sumber nitrogen adalah ammonium nitrat, ammonium sulfat, dan urea. Jika ezim ekstraseluler yang dihasilkan oleh fungi banyak, maka degradasi akan berlangsung lebih cepat. Sebaliknya, jika enzim ekstraseluler yang dihasilkan oleh fungi sedikit, maka degradasi akan berlangsung lebih lama

3) $\mathrm{pH}$

Dalam proses degradasi, $\mathrm{pH}$ merupakan faktor yang sangat penting karena enzim-enzim tertentu hanya akan mengurai suatu substrat sesuai dengan aktivitasnya pada $\mathrm{pH}$ tertentu. Jika pH sesuai dengan aktivitas enzim, maka kerja enzim ekstraseluler untuk mendegradasi substrat akan optimal.

4) Suhu

Peningkatan suhu menyebabkan energi kinetik pada molekul substrat dan enzim meningkat, sehingga degradasi juga meningkat. Namun suhu yang terlalu tinggi dapat menyebabkan rusaknya enzim yang disebut denaturasi, sedangkan suhu yang terlalu rendah dapat menghambat kerja enzim. Biodegradasi tidak dapat berjalan dengan baik jika kerja enzim terhambat atau struktur dari enzim tersebut rusak.

5) Kelembaban

Rendahnya kelembaban dapat menyebabkan berkurangnya kelarutan nutrient di dalam substrat. Sedangkan tingginya kelembaban dapat menyebabkan berkurangnya enzim yang dihasilkan. Proses biodegradasi akan berlangsung lebih lama jika jumlah enzim berkurang.

\section{Mikroorganisme Pendegradasi Plastik}

Terdapat 90 genus mikroorganisme yang memiliki kemampuan untuk mendegradasi plastik dari jenis fungi dan bakteri diantaranya; Bacillus megaterium, Pseudomonas sp., Azotobacter, Ralstonia eutropha, Halomonas sp., Bacillus megatserium, Pseudomonas sp., Azotobacter sp., Ralstonia eutropha, Halomonas sp., dll digunakan untuk mendegradasi plastik (Chee, 2010). Selain itu, Bacillus brevis, Acidovorax delafieldii, Paenibacillus amyloticus, Bacillus pumilus (Hayase, 2004), Bordetella petrii (Kim, 2010), Pseudomonas aeruginosa (Lee S, 2010), Shewanella sp. adalah contoh bakteri pendegradasi bioplastik (Sekiguchi, 2010). 


\section{Analisis Fourier Transform InfraRed (FTIR) dan Scanning Electron Microscopy (SEM)}

Fourier Transform InfraRed (FTIR) merupakan alat yang digunakan untuk mengukur transmitan atau absorban suatu sampel dalam bentuk panjang gelombang. Spektroskopi inframerah ini berfokus pada radiasi elektromagnetik pada rentang frekuensi $\left(400-4000 \mathrm{~cm}^{-1}\right.$ wavelength), yang merupakan ukuran unit untuk frekuensi. Fourier Transform InfraRed (FTIR) sangat diperlukan untuk analisis kualitatif (identifikasi) dari senyawa organik karena setiap senyawa memiliki puncak struktural yang berbeda. Selain itu, setiap kelompok fungsional memiliki panjang gelombang yang berbeda. Sehingga pada proses biodegradasi plastik dapat diketahui perubahan gugus fungsional yang terjadi.

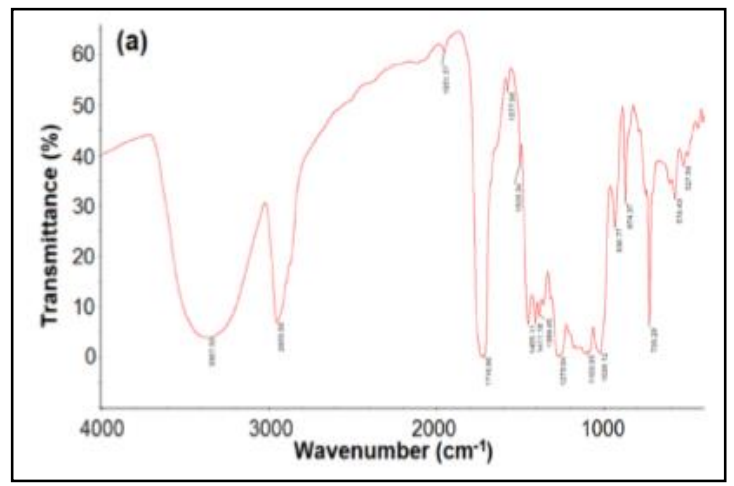

A) Spektrum FTIR biodegradasi plastik sebelum perlakuan

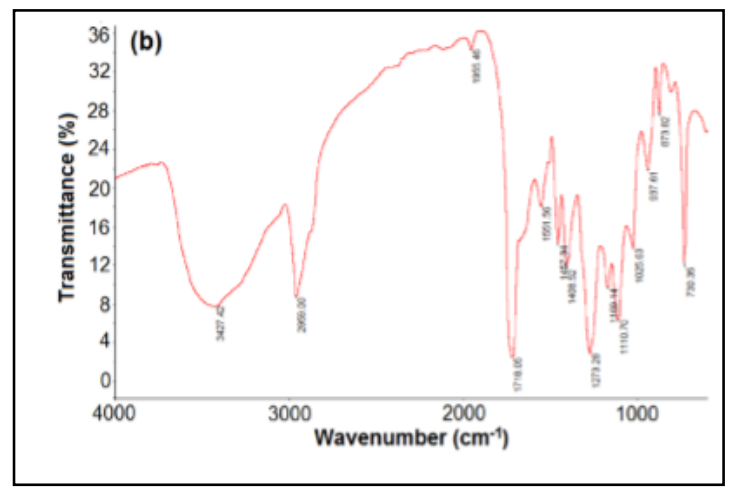

B) Spektrum FTIR biodegradasi plastik setelah perlakuan

Gambar 1. Spektrum FTIR plastik sebelum dan sesudah proses biodegradasi (Thi Cam Ha Dang dkk, 2018)

Scanning Electron Microscope (SEM) adalah alat yang digunakan untuk mengetahui bentuk morfologi permukaan padatan atau senyawa. Scanning Electron Microscope adalah suatu tipe mikroskop elektron yang menggambarkan permukaan sampel melalui proses scan dengan menggunakan pancaran energi yang tinggi dari electron dalam suatu pola scan raster. SEM dapat mengamati struktur maupun bentuk permukaan yang berskalah lebih halus, dilengkapi dengan EDS (Electron Dispersive $\mathrm{X}$ ray Spectroscopy) dan dapat mendeteksi unsur-unsur dalam material.

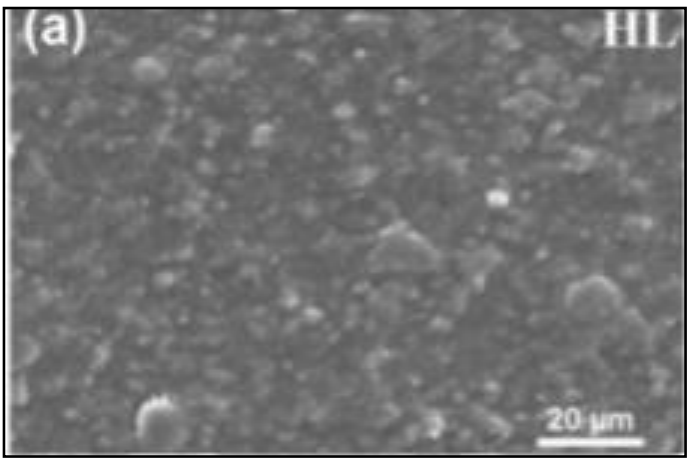

A) Gambar SEM biodegradasi plastik sebelum perlakuan

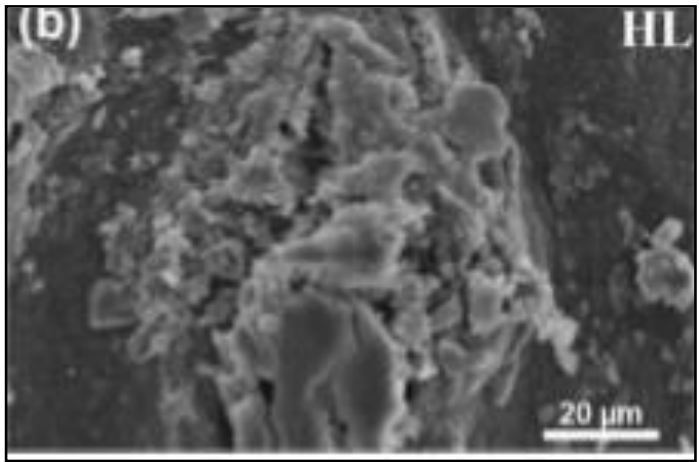

B) Gambar SEM biodegradasi plastik setelah perlakuan

Gambar 2. Perubahan morfologi plastik sebelum dan sesudah proses biodegradasi dengan analisis SEM (Thi Cam Ha Dang dkk, 2018)

\section{Hasil Penelitian Sebelumnya}

Berikut ini merupakan hasil penelitian sebelumnya mengenai penelitian terkait biodegradasi plastik oleh mikroorganisme 
Tabel 1. Hasil Penelitian Sebelumnya

\begin{tabular}{|c|c|c|}
\hline Judul Paper, tahun & Penulis & Hasil Penelitian \\
\hline $\begin{array}{l}\text { Penanganan Limbah Plastik dengan } \\
\text { Teknologi Pirolisis dan Biodegradasi } \\
\text { dengan Bakteri Pseudomonas sp., } 2011\end{array}$ & $\begin{array}{l}\text { Hamid, Rusdianto } \\
\text { dkk. }\end{array}$ & $\begin{array}{l}\text { Pseudomonas } \text { sp. menunjukkan persentase } \\
\text { penurunan massa limbah plastik LDPE sebesar } \\
2,2411 \% \text { selama satu bulan. }\end{array}$ \\
\hline $\begin{array}{l}\text { Microbial Degradation of Plastic } \\
\text { (LDPE) \& Domestic Waste by Induced } \\
\text { Mutations in Pseudomonas putida, } \\
2014\end{array}$ & $\begin{array}{l}\text { Muralidhar S. } \\
\text { Talkad dkk. }\end{array}$ & $\begin{array}{l}\text { Pseudomonas putida dapat mendegradasi } \\
\text { polyethylene sebanyak } 20.54 \% \text { massa yang } \\
\text { hilang dengan bakteri anaerobik }\end{array}$ \\
\hline $\begin{array}{l}\text { Polyetylene Degradation by } \\
\text { Pseudomonas putida, } 2015\end{array}$ & Al Jailawi dkk. & $\begin{array}{l}\text { Pseudomonas putida dapat mendegradasi limbah } \\
\text { plastik LDPE optimum pada nilai keasaman }(\mathrm{pH}) \\
7 \text { dan temperatur } 37^{\circ} \mathrm{C} \text {. }\end{array}$ \\
\hline $\begin{array}{l}\text { Potensi Bakteri Pseudomonas sp. dan } \\
\text { Ochrobactrum sp. yang di Isolasi Dari } \\
\text { Berbagai Sampel Tanah Dalam } \\
\text { Mendegradasi Limbah Polimer Plastik } \\
\text { Berbahan Dasar HDPE dan LDPE, } \\
2017\end{array}$ & $\begin{array}{l}\text { Riandi, M. Inas, } \\
\text { dkk. }\end{array}$ & $\begin{array}{l}\text { Pseudomonas aeruginosa dapat mendegradasi } \\
\text { limbah plastik LDPE sebesar } 18,75 \% \text { dengan } \\
\text { metode gravimetri. }\end{array}$ \\
\hline
\end{tabular}

\section{PENUTUP}

Berdasarkan hasil penelitian menurut Rudianto dkk, Talkad dkk, Al Jailawi dkk dan Inas dkk bahwa bakteri Pseudomonas sp. mampu mendegradasi plastik dengan persen penyisihan berkisar antara 2-19\%. Dengan demikian, bakteri ini mampu menjadi biodegradator pilihan untuk melakukan biodegradasi plastik.

\section{DAFTAR PUSTAKA}

Al-Jailawi, Majid H, dkk. 2015. Polyethylene degradation by Pseudomonas putida S3A, 90-97. Bhardwaj, Himani, dkk. 2012. Microbial Population Associated With Plastics Degradation. DOI: http://dx.doi.org/10.4172/scientificreports.272

Chee JY, dkk. 2010. Bacterially Produced Polyhydroxyalkanoate (PHA): Converting Renewable Resources into Bioplastics, edited by Mendez Vilas A. Applied

Chua ASM, Takabatake H, dkk. 2003. Production of polyhydroxyalkanoates (PHA) by activated sludge treating municipal waste water: Effect of $\mathrm{pH}$, Sludge Retention Time (SRT), and Acetate Concentration influent. Water Res; 37(15):360-361.

DOI: https://doi.org/10.1016/S0043-1354(03)00252-5

Dang, T. C. H., Nguyen, dkk. 2018. Plastic degradation by thermophilic Bacillus sp. BCBT21 isolated from composting agricultural residual in Vietnam. Advances in Natural Sciences: Nanoscience and Nanotechnology, 9(1), 015014.

DOI: https://doi.org/10.1088/2043-6254/aaabaf

Fadlilah, Fiki Rahmah dan Shovitri, Maya. 2014. Potensi Isolat Bakteri Bacillus Dalam Mendegradasi Plastik dengan Metode Kolom Winogradsky. Jurnal Sains dan Seni ITS Vol 3 No. 2

DOI: $10.12962 / \mathrm{j} 23373520 . v 3 i 2.6730$

Hamid, Rusdianto, dkk. 2011. Penanganan Limbah Plastik dengan Teknologi Pirolisis dan Biodegradasi dengan Bakteri Pseudomonas sp. Jurnal Universitas Hasanuddin

Hayase N, Yano H, Kudoh E, Tsutsumi C, Ushio K, Miyahara Y, Tanaka S, Nakagawa K. 2004. Isolation and characterization of poly (butylene succinate-co-butylene adipate)degrading microorganism. J Biosci Bioeng 2004; 97: 131-133

DOI: https://doi.org/10.1016/S1389-1723(04)70180-2

Inas Riandi, dkk. 2017. Potensi Bakteri Pseudomonas sp. Dan Ochrobactrum sp. Yang Di Isolasi Dari Berbagai Sampel Tanah Dalam Mendegradasi Limbah Polimer Plastik Berbahan Dasar High Density Polyethylene (HDPE) Dan Low Density Polyethylene (LDPE). Simbiosis Journal of Biological Sciences, $5(2), \quad 58$. DOI:10.24843/jsimbiosis.2017.v05.i02.p05 
Joshi PA, and Jaysawal SR. 2010. Isolation and characterization of poly- $\beta$ hydroxyalkanoate producing bacteria from sewage sample. J of Cell and Tissue Research. Vol 10 2165-2168 DOI: http://dx.doi.org/10.1155/2013/752821

Kim M, Park S. 2010. Degradation of poly (Llactide) by a mesophilicbacterium. J Appl Polym Sci 2010; 117: 67-74. 36

DOI: 10.1002/app.31950

Lee S, Kim M. 2010. Isolation of bacteria degrading poly (butylenesuccinate-co butylene adipate) and their lip A gene. Int Biodeterior Biodegrad 2010; 64: 184-190.

DOI: https://doi.org/10.1016/j.ibiod.2010.01.002

Purwaningrum, Pramiati. 2016. Upaya Mengurangi Timbulan Sampah Plastik di Lingkungan.

JTL Vol 8 No.2, Desember 2016, 141-147

DOI: http://dx.doi.org/10.25105/urbanenvirotech.v8i2.1421

Priyanka N, Archana T. 2011. Biodegradability of Polythene and Plastic by the Help of Microorganism: A Way for Brighter Future. J Environment Analytic Toxicol 1:111. doi: $10.4172 / 2161-0525.1000111$

DOI: $10.4172 / 2161-0525.1000111$

Sekiguchi T, Sato T, dkk. 2010. Isolation and characterization of bidegradable plastic degrading bacteria from deep-sea environments. Rep Res Dev 2010; 11: 3341.

DOI: 10.5918/jamstecr.11.33

Talkad, Muralidhar S. 2014. Microbial Degradation of Plastics (LDPE) \& DomesticWaste by Induced Mutation in Pseudomonas putida . Vol.1

DOI: $10.9790 / 2402-1209033440$

Vatseldutt, Anbuselvi S. 2014. Isolation and Characterization of Polythene Degrading Bacteria from Polythene Dumped Garbage. Int J Pharm 2014; 25(2): 205-206. 